\title{
NEXUS BETWEEN LANDSCAPING AND PATRONAGE IN YOUTH CENTRES IN SOUTHWEST NIGERIA
}

\author{
Omotoso, Kayode A. ${ }^{1}$ and Ayeni, Dorcas. A. ${ }^{2}$ \\ ${ }^{1}$ Mr. Omotoso, Kayode A., Federal University of Technology, Akure, NIGERIA, \\ benkol078@gmail.com \\ ${ }^{2}$ Dr. Ayeni Dorcas, Department of Architecture, Federal University of Technology Akure, NIGERIA. \\ daayeni@futa.edu.ng; dorcasayeni2@yahoo.com
}

\begin{abstract}
:
Building a youth centre is a development effort in which government and non-government organizations engage youth to help meet their basic personal and social needs. However, this effort is usually bedevilled by the problem of poor patronage. The research investigates how Landscaping can improve youth centres' patronage by reviewing and analysing relevant articles and conducting case studies of a selected youth centre in southwest Nigeria. The research explores literature review on youth centre patronage and Landscaping, and carried out field search of two (2) selected youth centres in southwest Nigeria; to assess the quality of facilities, incorporated landscaping elements and level of patronage. Qualitative content analysis was used to underscore the concept of patronage and Landscaping of youth centres, identify perspectives and gaps in the literature, and analyse data input from case studies. The paper identifies from literature factors affecting patronage of facilities and establishes the link between Landscaping and some factors affecting patronage. Importantly, it reveals that fusing landscaping elements into youth centres is poor, especially at the local scene. The study proposes future works Based on the findings on benefits of Landscaping to stimulate patronage, relationships between the degree and duration of impact, among others, to aid the design, implementation and management of a more efficient landscape environment for patronage. It recommends that youth centre landscaping facilities could be used to market its services. The paper identifies gaps in the literature, showing that adequate attention has not been shifted into the direction of this research. Consequently, the paper is a starting point towards more detailed research on the impact of Landscaping on patronage to address gaps in existing knowledge.
\end{abstract}

Keywords: Architectural Products, Landscaping, Patronage and Youth Centre. 


\section{INTRODUCTION}

The first noticeable formative appraisal of any place or people is through the physical structures and the overall environmental portrait. Other indices of estimation come next. It is highly appropriate to note the prejudicial impact this initial impression has on the subsequent decisions of the observer. In their various molds, architectural products constitute a more major proportion of this appraisal because image laundering is largely improved with architectural media. The prejudicial impact of this initial impression and subsequent judgments of the observer becomes one of the primary conditions for architectural products' patronage. Patronage generally refers to the support, encouragement, privilege, or financial aid that an organization or individual bestows. It is burnout of a desire to be committed to an organization based on its facility and service quality or perceived facility and service qualities (Webster Dictionary, 2012). In the context of this research, Users' patronage entails users' visitation to a facility of choice to consult the services and make use of its resources and to satisfy their objectives of visiting.

Low patronage and underfunding have been identified as the most fundamental problem of youth centers, especially in developing countries like Nigeria. Low patronage of a Youth Centre affects the usage of the facilities and the morale of Youth workers, maintenance of facilities and sustenance of program activities. Generally, patronage of youth centers has been very low in developing countries. This lukewarm attitude to youth development is, to some extent, a reflection of low patronage by proprietors of Youth development centers (Eric, 2017). In finding solutions to the problem of patronage, one may ask about the role that architectural product could play to improve patronage. Furthermore, like it was said earlier, people always encounter architectural products first before experiencing the actual service in any environment. However, Architectural products are very vast in terms of number. However, core among many architectural products capable of inducing users or observers of architectural products for actual patronage and repeat patronage is the component of landscaping in buildings considering its many benefits.

It is noteworthy that Nigerian architecture is not deficient in creativity. Considering the materials and technology available to it, creativity is not lacking in architectural massing and functional interior space arrangement. However, there is inadequacy in the landscaping of most sites in which these creative outputs are sited. Therefore, to improve patronage of the youth center, attention must not only be on creating architectural massing and functional interior space arrangement, but an effort must be made to integrate purposefully designed landscaping components into the development of the youth center. With the integration of elements of landscaping, both softscape and hardscape, the aesthetic quality, perception quality, and environmental quality of the youth development center will improve and thereby enhance the attraction of users for patronage.

\section{YOUTH CENTRE AND PATRONAGE ISSUES}

Previous works of literature into Youth development Centre have been centred around a review of program and policy frameworks for practical youth work, for instance, Bond (2010), in his study, affirmed the two assumptions upon which the foundation of various youth policy frameworks are built, the deficit assumption that perceived 'Youth' as a transitional state, emphasizing a safe passage to adulthood. The assumption described youth as transitioning, having emerging identities, powerless and vulnerable, less responsible and dependent, ignorant, prone to risky behaviours and rebellious (Bessant \& Watts, 2007). The approach viewed youth often as a 'problem' that has to be solved (Brent, 1997). The alternative assumption to the deficit approach is the assets or capability approach, which builds upon youth resources. These assets include connectedness and feeling valued, attachment to pro-social institutions, the ability to navigate in multiple cultural contexts, commitment to civic engagement, good conflict resolution and planning for future skills, a sense of personal responsibility and good moral character, self-esteem and confidence in one's efficacy, and a sense of a larger purpose in life (Eccles \& Gootman, 2002). Building a policy framework for youth interventions around these assumptions undoubtedly affects the patronage or participation of youth in targeted interventions. While deficit assumptions viewed young people as passive consumers of services organized by professionals, the asset assumptions see them as active participants who articulate their needs and shape a relevant response (Paterson, 2008). Bond (2010) suggested a holistic, integrated and bottomup approach for developing a youth policy framework and establishing youth centres. This approach suggests that policy intervention planning, programs and other youth interventions should always begin with the youth, and by this, patronage of youth interventions is likely going to improve.

The other issue raised in literature that affects youth centre patronage and participation is how attractive the centres are. For example, Leicester National Youth Agency (2008) opined that Youth centre facilities must be appealing and of high quality if they are to assure that young person is valued. Such reassurance is vital for increase patronage. Again, cost, distance, social discrimination and accessibility are factors also found to 
influence the patronage of social facilities (Nash, 1975; Lewis, 1977). This agrees with Mitchell and Town (1977); Pooler (1995) argues that two critical factors influence the pattern of patronage of facilities, Youth Centre inclusive. The two factors, according to them, are accessibility and time spent in reaching a particular facility or location in space. Onyando (2018) has grouped these identified factors as Institutional (facility) factor, Policy factor, Service provider factor and Client/Adolescent and youth perceptions.

Ecological research (Nebel, 1990) is another stream relevant to patronage. The studies argue that people will be more significant in places where the conditions are close to the ideal and lesser in number in places where habitat conditions are undesirable. Usually, animal populations migrate to places that have more ideal conditions for living. These notions also apply to youth behaviour. Findings have also shown that satisfaction thus has a link with patronage (Nadude \& Akahome, 2017; Cherdchamdol \& Sriboonjit, 2011).

\section{RELEVANCE OF LANDSCAPING TO YOUTH CENTRE PATRONAGE}

Landscaping is relevant to Patronage in many ways; this is because Landscaping has been found to have a significant link with many variables that influences Patronage. For instance, findings of Onyando (2018); Australian National Youth Agency (2008); Kumar and Malik (2013); Cherdchamdol and Sribbnjit (2011), among others, linked Patronage with quality of facilities in terms of attractiveness and its appeals to the perception and satisfaction of users, landscaping has been found from literature as a critical component to improve attractiveness and usability of any building. Landscaping combines the elements of art and science to create a functional, aesthetically pleasing extension of indoor living to the outdoors (Dewayne, 1983). Landscaping has been defined as the art of creating a land scenario to get a good atmosphere for human comfort using fauna, flora and complex landscape elements as the building blocks (Musa, 2006). According to Fadamiro and Atolagbe (2006), "Landscaping implies that process of shaping, modifying and creating an outdoor scene, to effectively express all the functional and supportive attribute of the public domains in the urban environment." They refer to the public domain here as the spaces in an urban environment such as parks, markets, streets, playgrounds and other open spaces collectively shared by the people within which most of the day-to-day experiences occur. Bien (2019) also defines Landscaping as "a science and an art of modifying visible features of a land to make it look appealing and inviting." Ayeni (2012) opined that Landscaping elements, both natural and artificial, are used to create a befitting visual presentation within the built environment, and the impact of this cannot be overemphasized. Deductively, good Landscaping could play a critical role in making a building more functional and appealing with provable tendencies of enhancing comfort, satisfaction and Patronage.

The research findings of Onyando (2018); Australian National Youth Agency (2008); Kumar and Malik (2013); Cherdchamdol and Sribbnjit (2011) establishes that there is a link between Patronage and quality of facilities in terms of attractiveness and its appeals to the perception and satisfaction of users, again, Landscaping has been found as a critical component to improve attractiveness, comfort and usability of any building in many ways. For instance, Researchers have identified ambient conditions as a factor that affects perceptions of and human responses to the environment and services. Lovelock (2002) opined that ambience is, in general, more important in service settings because customers, as well as employees, often experience the firm's facility. He said that ambience can aid or hinder the accomplishment of both internal organizational goals and external marketing goals. It is regularly perceived that when a guest visits a cafe, for instance, he might want an environment, which would cause him to feel good, comfortable and relaxed during the length of his stay. Temperature can be a factor, which can be unsavoury if not controlled satisfactorily. (Kurtich \& Eakin, 1993). According to (Weng et al., 2019), the study showed that ambience significantly and positively shaped customers' intentions to patronize. He argues that patronage decreases as the ambience condition deteriorates. The study also revealed that when the level of ambience increased, the intention to Patronage increased. Ambiance has positive and significant relationships with Intention to Patronage (Njite et al., 2015).

Unlike the consumers of tangible goods, consumers of services have a limited number of cues to assess satisfaction. Therefore, consumers utilize several peripheral cues besides the core product to make their decisions. In many cases, the physical environment provides a tangible cue to evaluate service products. In this way, Booms and Bitner (1982) opined that the physical environment could be perceived as an important element used to assess and determining consumer satisfaction with the service provided. Due to the inseparability of services, consumers have to be present in the physical environment to consume and experience the product. As a result of this simultaneity, Bitner (1992) suggests that the premises or place of consumption significantly role in the consumer's overall perception of satisfaction and behavioural intentions. 
Landscaping is considered critical to Patronage in a service environment because it is usually the first thing customers see before their actual service experience. Effective landscape spaces with elements such as benches for sitting, easily navigable pathways, choice greenery, unique elements of moving water, among others, create an inviting atmosphere. Landscaping at its best can create an atmosphere that persuades people to come in and experience place affordance and service. Landscaping has the power to make public settings stand out from similar ones in the area. Good Landscaping is not just a means of keeping the building's exterior neat; it is something that can add to the corporate image of any establishment, including a youth centre, thereby encourage Patronage.

\section{SOCIAL AND PSYCHOLOGICAL IMPACT OF LANDSCAPING ON YOUTH DEVELOPMENT}

Youths, especially from developing nations, have been inflicted by so many ills, among which are: Inadequate parental care; Moral decadence in the society; Lack of appropriate role models; Religious fanaticism; Cultism; Political manipulation of youth organizations; Unemployment and under-employment; Poverty; Poor education; Lack or insufficient of suitable sports and recreational facilities; Breakdown of family values; Indiscipline; Identity crisis; Lack of self-identity and low self-esteem; mounting health and social welfare problems and A sense of hopelessness. (Federal Government of Nigeria, National Youth Policy and Strategic Plan of Action, 2001). These enormous problems undoubtedly subject an average youth to a lot of mental and psychological stress daily. Therefore, it is important to review how Landscaping can help reduce the impact of social and psychological problems facing an average Nigeria Youth.

The landscape is developed, and its construction has a social aspect, especially nowadays when it becomes more and more important to make the surrounding environment so that helps people communicate and spend time outdoors. Landscape is the place where social and ecological systems meet. Social and ecological systems are two dimensions, which cannot be separated. In simple terms, it is clear that nature affects people and people affect nature (Conrad, 2017). People's engagement with places either for living, work or play negatively or positively influence their lives, their opportunities; it affects personal and communal happiness, identity and the sense of belonging (Speck, 2012; Montgomery, 2013).

The group of Heschong Mahone discussed a study that concentrated on the effect of the view from a classroom window on the students' performance. They conducted this study on 500 fundamental school classrooms in thirty-six schools. Sufficient numbers of windows have the view of primary trees or a playground, and parking area could positively affect the students' performance. (Heschong Mahone Group, 2003; Charles, 2010). Moreover, Wells and Evans (2003) have discovered that being surrounded by natural views decreases the stress on children and increases social interaction between neighbours, decreases violent behaviour; inand natural views positively impact human physical health (Matsouka, 2008; Vnkatesha, 2014). The findings of Sullivan et al. (2004) revealed that trees and grass are related to the level of social activity in outdoor spaces. Research has also shown that having larger yard trees and trees planted along streets within the neighbourhoods contributes to reducing crime rates. Taking a walk in a natural landscape with plants and trees has positively impacted attention and memory (Marc, 2003). Green views and access to green spots in cities help regain attention and relieve the everyday pressures of living in poverty.

Again, in the study conducted by Medhat and Kenawy (2016) on the "Impact of outdoor landscape on students' social and Environmental behaviour," it was argued that the absence of landscape in schools is a big fault, which affects the social and environmental behaviour of the students. They further assert their view by saying that the school landscape can assume a huge part in delivering these results, giving protected, invigorating environments where students can study, explore, regardless of their educational needs. Kuo's (2001) research on Coping with Poverty: Impacts of Environment and Attention in the Inner-City Environment and Behavior report considerable evidence which suggests that exposure to "green" environments can enhance human effectiveness and make life's demands seem manageable. Shaybani (2015) categorically stated that landscape is part of the environment; thus, environment and humans have a dynamic and reciprocal relationship, the landscape has such an affordance. Indeed, landscape can create peace and cheerfulness for users due to its affordance.

Additional Studies proved how that landscape could influence people's behaviour and performance. Studies on playscapes in kindergarten have shown that landscape has an impact on children's social interaction, and creative thinking also affects emotions and helps in self-development (Fjortoft, 2004; Fjortoft \& Sageie, 2000; Owens, 1997). The contact with nature affects the social interactions, academic performance, mental and physical health, students' satisfaction and environmental behaviour by providing students' attention to green spaces, which help them to have clear thinking and reduce life stress (Nancy \& Wells, 2003). Contact with nature has a positive influence on students' health as plants reduce blood pressure and lower the tension 
related to stress as well as reduces anger and fear; besides that, researchers set up that attention deficit disorder (ADD) symptoms in children are reduced after contact with green areas (Matsouka, 2008; Berto, 2005; Cimprich, 2003;)

According to Medhat and Kenawy (2016), the schools' landscape can help increase achievement and confidence, improve behaviour and health, and in addition, helps students to develop an extensive range of skills. A well-designed outdoor environment rich in green areas and other landscape elements helps to reducereduce the stress surrounding the students and, by its turn, enhances their academic performance and social behaviour.

\section{LANDSCAPE MANAGEMENT AND MAINTENANCE}

Unlike the static Architecture work and urban monuments, landscape design depends solely on the constant maintenance and management, ranging from cleaning moving, pruning and even renovation and replacement for it to perform its many functions. "The landscape maintenance is defined as the work undertaken in order to keep and restore every facility of landscape elements to an acceptable standard", (Musa, 2006). Maintenance of landscape is necessary: i. to retain the value of the investments ii. To maintain a project in a condition in which it will continue to fulfill its functions. And iii. To present a good appearance of the project, (Musa, 2006).

Qualities like modernity, innovation, straightforwardness or custom could be reflected in the landscaping of public facility setting, the effect of good landscaping on structures and the neighbourhood and the entire cityscape cannot be overemphasized. Effective and functional landscaping can be carried out and maintained to serve its purpose consistently. Indeed, even the most multifaceted, outwardly attractive, visually engaging and bleeding edge landscape designs will not produce positive outcome/result at the long run without cautious upkeep and regular maintenance and management, this ought to be given a significant consideration in landscape planning and development (Duval Landscape Maintenance, 2021).

Several factors are responsible for decay of landscape they include: Environmental factors: These include solar radiation, precipitation, air constituents, solid and liquid contaminants, exetera. These may affect the rate of plants growth, timber and concrete elements such as the walkways, furniture, kiosks and so on. Biological Defect: Some fungi, such as wet dry rot; insects such as beetles, pests and bacteria's may affect both the soft and hard landscape elements. These may dealt with the use of pesticides, insecticides, fungicides etc. Construction fault: poor supervision, workmanship and technology are the main faults of landscape design and maintenance. Defects in the landscape element: this affect the management and maintenance of the design such as defect in concrete, timber and other landscape elements. Users' fault: If the users are not considering the way and manner to use the project according to specifications of the designer, it may lead to the rapid devastation of the project which eventually causes the complexity in the management.

Landscaping design must be sustainable for simplicity of upkeep and management. Sustainable landscape should be designed to be both appealing, well blended with and in balance with the neighbourhood environment and climate and should require little inputs such as compost, pesticides and water for sustenance. Sustainable landscaping starts with suitable, functional, cost-efficient and visually satisfying design which must be friendly to the ecosystem and maintainable (Loehrlein, 2010)

\section{METHODOLOGY}

Essentially, the sources of data utilized in this study were both primary and secondary data. The primary data were obtained directly from the field through direct observation, case studies and personal interviews. The case studies carried out were based on a purposive sampling of selected Youth centers in southwest Nigeria. One purposively drawn from 5 prototype samples of National Youth development centers in Southwest Nigeria representing public youth centres and the second representing private-sector youth facilities in the region. On this basis, the selected case studies are National Youth Development Centre (NYDC), Ode-Omu, Osun State, and Don Bosco Youth Centre, Akure, Ondo State (see Plate 1 and 2 below). Two (2) personal interviews were conducted each for the Youth Centre Manager under study. The interviews were open-ended such that the researcher generated additional questions based on the flow of the discussions. Many of the questions centered on the operations and activities of each center, the issues of patronage and the factors responsible. Secondary data were generated from relevant scholarly textbooks, research thesis, research journals, and seminar papers. Finally, qualitative content analysis was used to analyze data. 


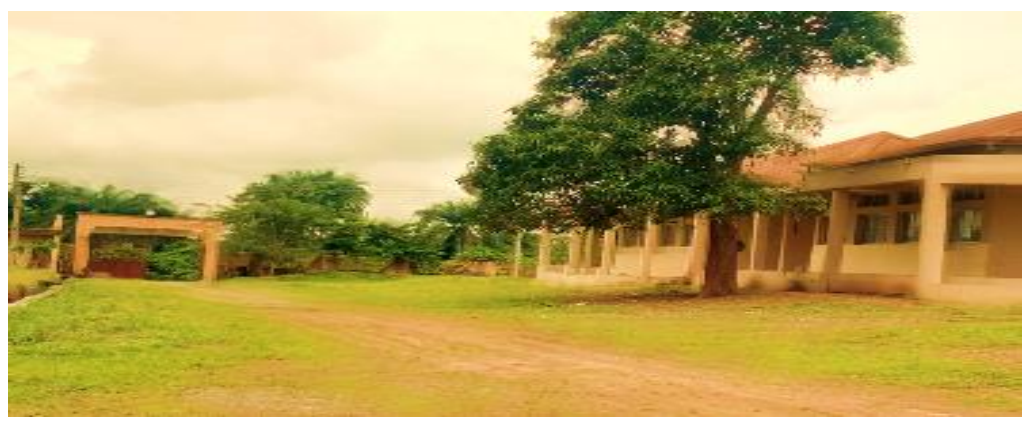

Plate 1: Showing Entrance of NYDC, Ode-Omu, flanked on the left by the multipurpose hall (Source:

Researcher's field work 2020)

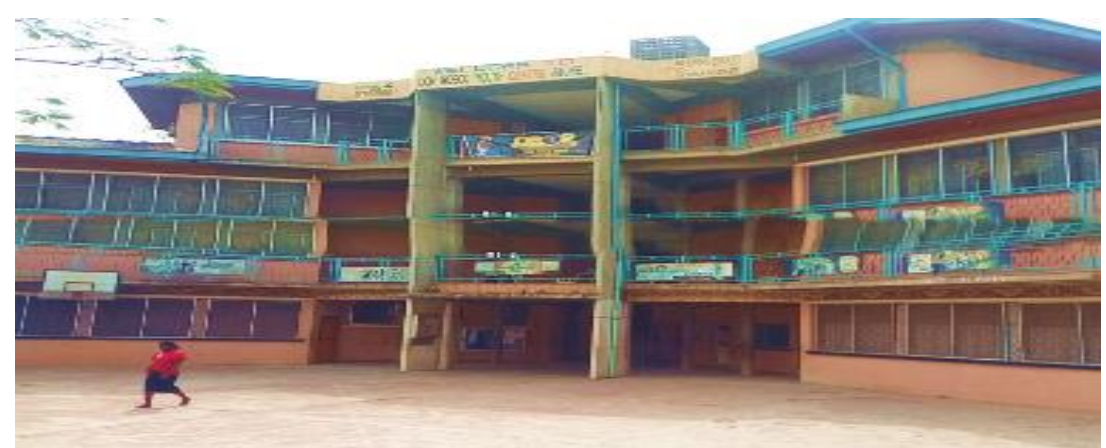

Plate 2: Front view Don Bosco Youth centre (Source: Researcher's field work 2020)

\section{RESULTS AND DISCUSSION}

\subsection{Youth centre and patronage}

It was revealed from case studies that youth centre in the southwest Nigeria have issues with patronage. Table 1 reveals the report of the interviews with managers of both youth centres (NYDC, Ode-omu and Don Bosco youth Centre, Akure).

Table 1: Report of Interview with Mangers of Youth Centres under study

\begin{tabular}{|c|c|c|c|c|c|}
\hline \multirow{2}{*}{$\mathrm{S} / \mathrm{N}$} & \multirow{2}{*}{ VARIABLES } & \multicolumn{2}{|c|}{ NYDC, Ode-Omu (Public) } & \multicolumn{2}{|c|}{$\begin{array}{l}\text { Don Bosco Youth Centre, } \\
\text { Akure (Private) }\end{array}$} \\
\hline & & Response & Remark & $\begin{array}{l}\text { Respons } \\
\mathrm{e}\end{array}$ & Remark \\
\hline 1 & $\begin{array}{l}\text { How will you assess the } \\
\text { Condition of facilities at this } \\
\text { centre }\end{array}$ & Good & structurally & good & structurally \\
\hline 2 & $\begin{array}{l}\text { How will you assess the } \\
\text { adequacy of the facilities at this } \\
\text { centre to support Youth } \\
\text { Development }\end{array}$ & Fairly good & & $\begin{array}{l}\text { Fairly } \\
\text { good }\end{array}$ & \\
\hline 3 & $\begin{array}{l}\text { How do you see the } \\
\text { Siting/location of facility }\end{array}$ & poor & $\begin{array}{l}\text { Accessibility/ } \\
\text { Way-finding is a } \\
\text { problem }\end{array}$ & $\begin{array}{l}\text { Fairly } \\
\text { good }\end{array}$ & $\begin{array}{l}\text { Way-finding is } \\
\text { a problem }\end{array}$ \\
\hline 4 & $\begin{array}{l}\text { The location/siting of this facility } \\
\text { affects its patronage }\end{array}$ & Yes & & No & \\
\hline
\end{tabular}




\begin{tabular}{|c|c|c|c|c|c|}
\hline 5 & $\begin{array}{l}\text { What is your assessment of } \\
\text { Patronage of this centre }\end{array}$ & Low & $\begin{array}{l}\text { No documented } \\
\text { evidence for } \\
\text { patronage }\end{array}$ & fair & $\begin{array}{l}40-60 \text { youth } \\
\text { daily at the } \\
\text { peak and at } \\
\text { low, } 10-20 \\
\text { persons daily }\end{array}$ \\
\hline 6 & $\begin{array}{l}\text { The facility is well branded to } \\
\text { show a Youth Friendly Centres }\end{array}$ & No & & No & \\
\hline 7 & $\begin{array}{l}\text { Fee Charging on admission to } \\
\text { use facility }\end{array}$ & Moderate & & free & \\
\hline 8 & $\begin{array}{l}\text { How will you assess the level of } \\
\text { maintenance of this centre }\end{array}$ & poor & $\begin{array}{l}\text { Owing to very } \\
\text { low funding }\end{array}$ & fair & \\
\hline 9 & $\begin{array}{l}\text { What is your assessment of the } \\
\text { funding of this centre }\end{array}$ & low & & fair & \\
\hline 10 & $\begin{array}{l}\text { Landscaping could improve } \\
\text { patronage }\end{array}$ & Not sure & & agree & \\
\hline 11 & $\begin{array}{l}\text { Improved aesthetic quality of this } \\
\text { facility could improve patronage }\end{array}$ & $\begin{array}{l}\text { Strongly } \\
\text { agree }\end{array}$ & & $\begin{array}{l}\text { Strongly } \\
\text { agree }\end{array}$ & \\
\hline 12 & $\begin{array}{l}\text { Elements/features of } \\
\text { Landscaping could improve } \\
\text { aesthetic quality of the facility }\end{array}$ & $\begin{array}{l}\text { Strongly } \\
\text { agree }\end{array}$ & $\begin{array}{l}\text { Paved walkways/ } \\
\text { road, outdoor } \\
\text { sitting/shade, } \\
\text { focal point, water } \\
\text { fountains/pool } \\
\text { etc. }\end{array}$ & $\begin{array}{l}\text { Strongly } \\
\text { agree }\end{array}$ & $\begin{array}{l}\text { outdoor } \\
\text { sitting/shade, } \\
\text { focal point, } \\
\text { water } \\
\text { fountains/pool } \\
\text { etc. }\end{array}$ \\
\hline
\end{tabular}

(Source: Researcher's field work 2020)

Findings reveals that the earlier had no reliable/documented data to assess patronage but deductions from interviews with the Centre's Principal emphasized problem of low patronage and the experience from the field trip to the centre corroborate this problem as there are no patronage throughout the period of the researcher's three different visits. From the later, deductions from the interview suggest a fair patronage although largely below what is expected (see table 1, item no 5 above).

Though, literature suggest cost as one of the problem for low patronage, however, the research findings seems to disagree to an extent with this conclusion. For instance, findings from case studies and the interview with the manager of Don Bosco Youth Centre, Akure reveals that despite the fact that all youth are admitted to the centre without any charges, on the average the patronage of the centre is below expectation. Patronage during the peak time was pegged between forty (40) and sixty (60) persons per day particularly during student vacations and special holidays. And at low, patronage drop to between ten (10) and twenty (20) (see table 1, item no 5 above). One would have thought that since youth admission to Don Bosco is done free of charge, patronage should have been more massive than they currently are. Again Findings from NYDC Ode-omu corroborate the fact that location is indeed a problem to patronage, this is because despite many facilities present, the centre is almost becoming a ghost of itself owing to low patronage because of obscure location. Indeed, the centre manager is of the opinion that "if the centre have been strategically located closer to where youth population is high, patronage could have been better" (see table 1, item no 3 and 4 for NYDC Ode-omu above).

\subsection{Youth centre patronage and landscaping}

Research findings revealed that landscaping has relationship with many factors affecting patronage mentioned in literature. Findings shows that Aesthetic quality, Comfort and Satisfaction, Ambience among others have relationship with patronage (Onyando, 2018 Australian National Youth Agency, 2008; Kumar \& Malik, 2013; Cherdchamdol \& Sribbnjit, 2011; Weng et al., 2019) and literature agreed that landscape have relationship with the listed variables. Findings shows that in the case of NYDC, Ode-Omu, nothing has been 
done as regards incorporation of landscaping component into the centre. Despite the abundant presence of natural vegetation, deliberate appropriated landscaping is absent. The basic element of landscaping like ornamental trees, flowers, shrubs, walkways, road seating furniture, Parking etc. is conspicuously missing (see Plates 3 and 4 below).

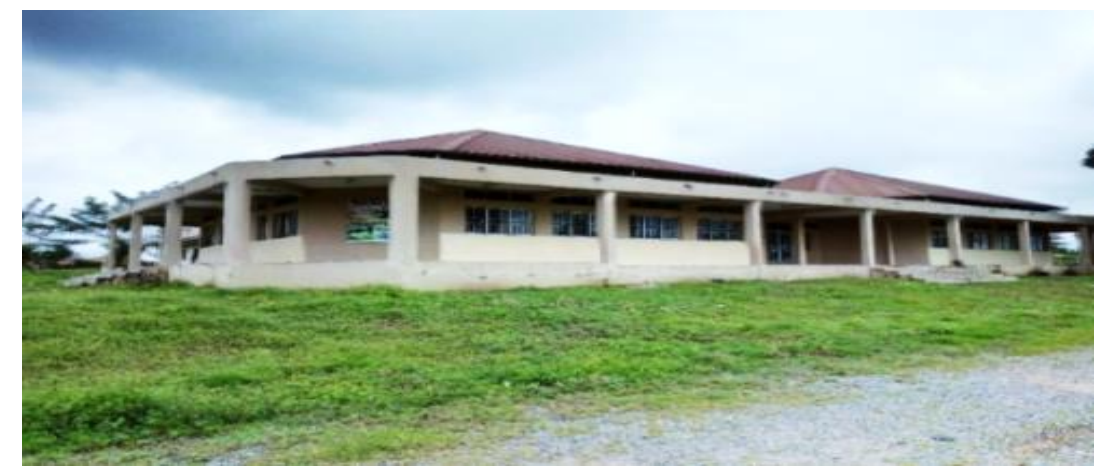

Plate 3: showing NYDC, Ode-Omu Multipurpose Hall without any Walkway connecting to other facilities at the centre

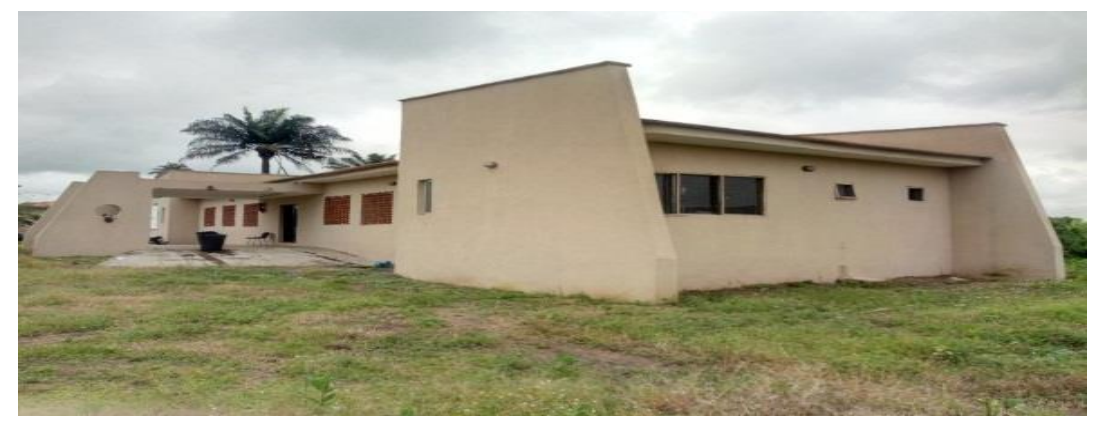

Plate 4: showing NYDC, Ode-Omu Admin Building without any Walkway connecting to other facilities as well as parking

Initially, the manager of NYDC Ode-omu is indifferent as to whether landscaping has any effect on patronage, this response is not unconnected to the insufficient understanding of landscaping constituents, however, both managers agreed strongly that improved aesthetic quality of their centre is capable of improving its patronage, they went forward to mention items such as paved walkways/ road, outdoor sitting/shade, focal point, water fountains/pool etc. as necessary items to improve aesthetic quality and consequently agreed that landscaping elements enhance aesthetic quality which is in agreement with the assertions of Dewayne (1983), Bien (2019) and Ayeni (2012) which links landscaping with visual aesthetics and appeal (see table 1, item no 10, 11 and 12).

At Don-Bosco Youth Centre considerable number of landscaping components is present, however, some facility lacks associated landscaping element to complement its function. For instance the sporting area is without Shelter/seating for spectators (see Plate 5 below). Some road seating furniture provided are without adequate shade or cover (see Plate 6 below).

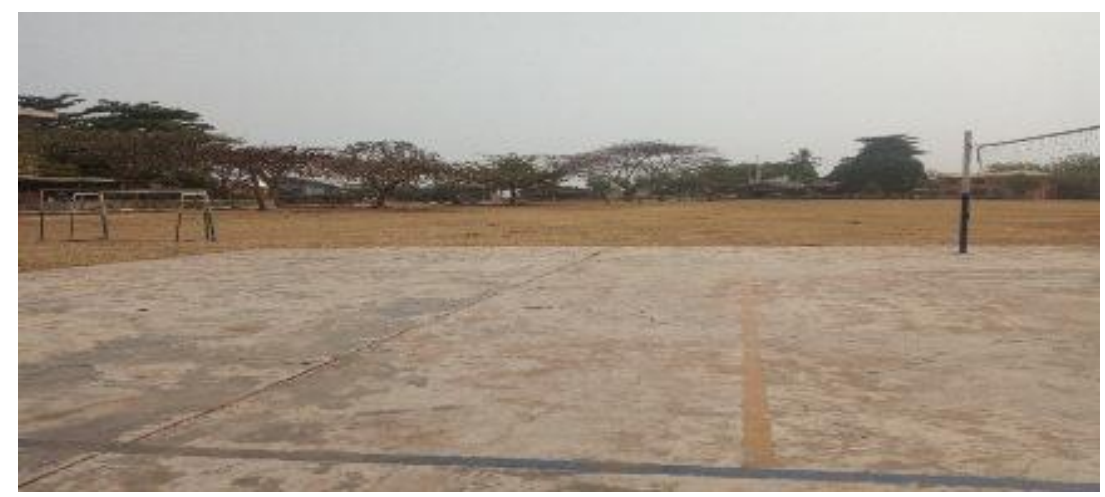

Plate 5: Showing football field and sport courts without any shelter for spectators (Source: researcher field work, 2020) 


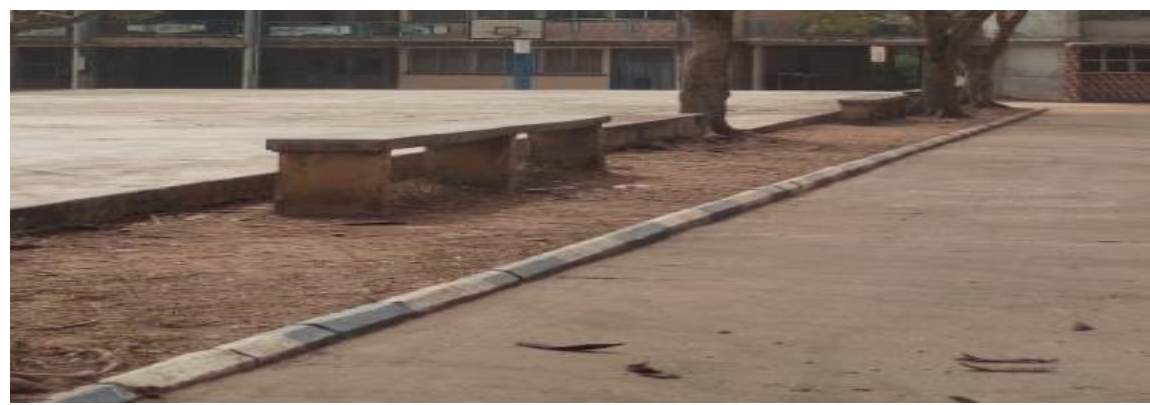

Plate 6: Showing outdoor seating without adequate shade (Source: researcher field work, 2020)

consequently, providing variable components of landscaping: 'softscape' and 'hardscape' including taking cognizance of basic principles of landscaping such as Rhythm and Balance, Focalization, Simplicity, Scale and Proportion, Unity and Variety, Accent and contrast improves the aesthetic quality of youth centre therefore become capable of inducing and enhancing patronage

\subsection{Social and psychological impact of landscaping on youth development.}

Having landscaping elements integrated adequately into youth centre environment afford users take advantage of the many social and psychological contribution of landscaping. Planting trees, shrubs, flowers in and around youth centre facility could help giving some psychological relieve to the youth and improve attention and memory (Marc, 2003). Having seats with adequate shelter strategically planted within the outdoor environment of youth centre including provision playground could aid social interaction and connectedness (Bill \& Greet, 2010). The functionality of the outdoor space within a youth centre can be improved by Landscaping. For instance, spaces like a Sitting areas, outdoor dining area, lounge, a garden, outdoor sport arena, swimming area can be created within the outdoor space to increase its efficiency. Benches and other sitting furniture can be provided where users can spend time while enjoying the beauty of nature (Deakin et al., 2007).

\subsection{Landscaping management and maintenance}

Even the most intricate, visually appealing and cutting-edge landscape designs will not see success without careful upkeep and regular maintenance; this should be a significant consideration for landscape designs. Findings from the interview suggest that attitude towards maintenance of the public facility is inadequate. The experience of poor maintenance at NYDC, Ode-Omu being a public facility, was linked mainly with insufficient funding. In contrast, with better access to financing at Don-Bosco Akure, the maintenance is fair. It is worth noting that at NYDC, Ode-omu is far more significant and adequate than what is available at Don Bosco, Akure but maintenance at the latter is better (see table 1, items no 8 and 9). For facilities, including landscaping, to continue to offer their many benefits, especially at improving factors that enhance patronage, management and maintenance should be essential. Care should be taken from landscaping planning and design, including decisions covering plant selection, choice of materials for landscaping, the long-term cost of maintenance, among others. By adequate management and maintenance of landscaping components, the life of the components is extended and thereby empowered to support patronage of a youth centre for a very long term.

\section{CONCLUSION AND RECOMMENDATION}

The primary aim of this study was to discover how elements or components of Landscaping could be used to enhance the patronage of Youth centres. Building Youth development centres is a good direction that all governments have to go. The centres should not be built as simply as another school but should be built to incorporate facilities including variables of Landscaping to service the overall need of the Youth; the need for empowerment, support and inspiration. Government and proprietors of youth centres should not stop at constructing the building components of the centre but are to ensure that the landscaping components are properly integrated and implemented into the building. A good landscape environment supports social interaction and connection, thereby enhances the social relationship, better attitude to life and aids more excellent emotional stability, help the mind refreshed by reducing stress and tension, and give room for renewed mindset for the more productive task. Effective and efficient use of Landscaping elements gives psychological relief, happiness and satisfaction to facility users and thereby supports patronage. Although factors affecting patronage are numerous, as discovered from literature, however, Landscaping impacts some factors that inform patronage. This is why it is crucial and non-negotiable that Landscaping elements should be incorporated into building public facilities such as a youth centre. This research can be used as 
starting point towards more detailed research on the impact of Landscaping on patronage.

Further investigation about the benefits of Landscaping to stimulate patronage intentions and actual patronage will further accentuate landscape design, implementation and maintenance as a critical part of the public building process. Further research should be carried out on the relationships between the degree of impact, duration of impact, time spent/length of stay in such deliberately designed Landscaping, and users' demographic and socio-cultural characteristics. This will aid Architects and Landscape designers in designing a more efficient landscape environment for patronage. The Youth centre landscaping facilities should be used as a marketing gimmick of the Youth centre services; by placing the Youth centre's beautiful landscape features or pictures on the internet, magazines and other mediums of visual communication to aid patronage.

\section{REFERENCES LIST}

Ayeni, D. A. (2012). Emphasizing Landscape Elements as Important Components of a Sustainable Built Environment in Nigeria. Developing Country Studies 2(8), 2224-607X (Paper) 2225-0565 (Online). http://www.iiste.org/Journals/

Berto, R. (2005). Exposure to restorative environments helps restore attentional capacity. Journal of Environmental Psychology,

Bessant, J., \& Watts, R. (2007). Sociology Australia, 3rd edn, Allen and Unwin, Sydney.

Bien, R. (2019). Landscape Design Ideas for a Creative Home Garden, Retrieved from http:// www.homedesignlover.com.

Bill, M., \& Greet, H. G. (2010). Site Furnishings: A Complete Guide to the Planning, Selection and Use of Landscape Furniture and Amenities, John Wiley \& Sons; 2010. p13, 14, 25,151,152.

Bitner, M. J. (1992). Servicescapes: The impact of physical surroundings on customers and employees. Journal of Marketing, 56(2), 57-71.http://dx.doi.org/10.2307/1252042

Bond, S. (2010). Integrated service delivery for young people: A literature review, a publication of Brotherhood of St Laurence

Booms, B. H., \& Bitner, M. J. (1982). Marketing services by managing the environment. The Cornell Hotel and Restaurant Administration Quarterly, 23(1), 35-40. http://dx.doi. org/10.1177/ 001088048202300107

Charles, C. (2010). Children contact with the outdoor nature. s.l., s.n., p. 23.

Cherdchamdol, P., \& Sriboonjit, J. (2011). The factors influencing customer satisfaction with chain budget hotels in Bangkok. Journal of Business Strategy and Execution, 3, 1-10.

Conrad, E. (2017). Human and Social Dimensions of Landscape Stewardship. In: The Science and Practice of Landscape Stewardship. Bieling, C., Plieninger, T. (eds.). Cambridge University Press, 2017, p. 3854.

Njite, D., Njoroge, J., Parsa, H., Parsa, R., \& van der Rest, J. (2015). "Consumer patronage and willingnessto-pay at different levels of restaurant attributes: A study from Kenya" Research in Hospitality Management 2015, 5(2): 171-180

Deakin, M., Mitchell, G., Nijkamp, P., \& Vreeker, R. (2007). Sustainable Urban Development: Volume 2; the Environmental Assessment Methods, Routledge Press; 2007. p365.

Dewayne, L. I. (1983). Basic Principles of Landscape Design http://www.uflib. ufl.edu/ufdc/?b=IR00000113\&v=00001

Duval Landscape Maintenance. (2021). 5 Qualities of effective landscaping. Retrieved from https://www.duvallandscape.com/5-Qualities-of-Effective-Landscaping-1-55.html; 
Eric, G. M. (2017). "Youth Centres" a publication of Whole Building Design Guide (WBDG) of National Institute of Building Sciences (2017),

Eccles, J., \& Gootman, J.A. (2002), Community programs to promote youth development, National Academy of Sciences' Board on Children, Youth, and Families, Washington DC.

Fadamiro, J. A. \& Atolagbe, A.M.O. (2006). "Urban environmental sustainability: A challenge to effective Landscaping in Nigeria" DimensiTenInikArsitekturvol. 34, July 2006; Pg. 46-70.

Fjortoft, (2004). Landscape as playscape, s.I.: s.n.

Fjortoft, \& Sageie, J. (2000). The natural environment as a playground for children, s.l.: s.n.

Federal Government of Nigeria National Youth Policy and Strategic Plan of Action. (2001).

Heschong Mahone Group. (2003). Windows and offices: A study of office worker performance and the indoor environment. Calfornia: California Energy Commission.

Kumar, S., \& Malik, S. (2013). An empirical study of factors affecting hotel customers' satisfaction from front office services \& facilities in Indian hospitality industry. A Journal of Economics and Management, 2(3), 1-8.

Kurtich, J., \& Eakin, G. (1993). Interior Architecture. New York: Van Nostrand Reinhold Publishers.

Lewis, D. (1977). "Estimating the Influence of Public Transport on Road Traffic Levels in Greater London", Journal of Transport Economic and Policy, Vol. II, No. 2.

Loehrlein, M. (2010). Sustainable Landscaping. Retrieved from http://sustainablelandscaping.us

Lovelock, C.H. (2002). "Classifying services to gain strategic insights". Journal of Marketing. 47(4):9-20.

Marc, S. F. (2003). "Benefits of landscape; the Benefits of Plants and Landscaping"

Matsouka, R. (2008). High school landscape and student performance. The University of Michigan.

Mehrabian, A., \& Russell, J.A. (1974). An Approach to Environmental Psychology. Cambridge, MA: Massachusetts Institute of Technology.

Medhat, R., \& Kenawy I. (2016). Impact of outdoor landscape on students' social and Environmental behaviour, a methodology conceptualization. A Conference Paper, https://www.researchgate.net/publication/303446266

Mitchell, C.G.B., \& Town, S.W. (1977). Accessibility of Various Social Groups to Different Activities. TRRL, SR 258, Crowthorne, England.

Montgomery, C. (2013). Happy City, Transforming Our Lives through Urban Design. London: Penguin Books.

Musa, M.A. (2006); Landscape in the Tropical Nigeria. Unpublished B.Sc. Project, Department of Architecture, ABU. Zaria.

Nancy, M., \& Wells, E. (2003). Environment and behavior, s.l.: s.n.

Nash, C. A. (1975). Economics of Public Transport. Longmans Inc. New York.

Onyando, O.J., Olocuh, M., \& Njuguna, S. (2018). "Factors Influencing Effectiveness of Youth Friendly Centres in Kenya: A Case of Kisumu County.". International Journal of Current Business and Social Sciences, Volume, 1 Issue, 7 pp., 78-98

Owens, P. E. (1997). Adolescence and the cultural landscape, s.l.: s.n.

Paterson, R. (2008). Youth innovation centre: business planning case, Tea Tree Gully, SA, $<$ www.teatreegully.sa.gov.au/webdata/resources Business_Planning_Case.pdf>. /files/Youth_Innovation_Centre_

Pooler, J. A. (1995). "The Use of Spatial Separation in the Measurement of Transportation Accessibility". Transportation Research. No. A 29. pp. 421-427.

Russell, J. A. \& Snodgrass, (1987). "Emotion and the Environment", in Handbook of Environmental Psychology, Daniel Stokols and Irwin Altman, eds. New York: John Wiley \& Sons, Inc., pp.245-81.

Speck, J. (2012). Walkable City, How Downtown Can save America, One Step at a Time, New York. North 
Point Press.

Vnkatesha, A. (2014). High school Landscape. America: University of Illinois at Urbana Champaign, s.l.: s.n. Webster Online Dictionary. (2012).

Wells, N. M., \& Evans G. W. (2003). Nearby nature. Environment and Behavior. , s.I.: s.n.

Weng, M. L., Kuching, S., Teck, W. J., \& Chin-Fern, E. G._ (2019). "Ambience and social interaction effects on customer patronage of traditional coffeehouses" Journal of Hospitality Marketing \& Management 